\title{
Irradiation, Stage of Maturity at Harvest, and Storage Temperature during Ripening Affect Papaya Fruit Quality
}

\author{
W.R. Miller and R.E. McDonald \\ U.S. Department of Agriculture, Agricultural Research Service, U.S. Horticultural \\ Research Laboratory, 2120 Camden Road, Orlando, FL 32803-1419
}

Additional index words. Carica papaya, quarantine treatment, postharvest quality, peel scald, lumpy fruit, decay, firmness, pulp color, $\mathrm{pH}$, soluble solids, flavor

\begin{abstract}
Solo-type papaya (Carica papaya L.) fruit at the mature green (MG) or onequarter yellow (QY) stage of maturity were imported through the Port of Miami, Fla., and either irradiated $(0.675 \mathrm{kGy})$ or not irradiated. Fruit condition and quality attributes were determined after ripening to the edible ripe stage at $25^{\circ} \mathrm{C}$ before and after storage for 7 days at 10,12 , or $15{ }^{\circ} \mathrm{C}$. The incidence and severity of peel scald was increased by irradiation regardless of storage and ripening regime; however, the degree of severity was dependent on fruit maturity at irradiation. Irradiated QY fruit tended to have the most serious incidence and severity of scald. Mature green fruit ripened at $25^{\circ} \mathrm{C}$ without storage had the lowest incidence of fruit with hard areas in the pulp ("lumpy" fruit). The QY fruit generally were second only to irradiated MG fruit stored at $10^{\circ} \mathrm{C}$ in incidence of lumpiness. Anthracnose sp. decay and stem-end-rots affected $53 \%$ of all fruit. The least decay occurred on fruit ripened at $25^{\circ} \mathrm{C}$ without storage, regardless of fruit maturity, and the most decay occurred on QY fruit with or without irradiation. Fruit ripened at $25{ }^{\circ} \mathrm{C}$ without storage had more palatable pulp $(5.5 \mathrm{~N})$ at the edible ripe stage than did fruit held in storage and then ripened. The effect of fruit maturity or irradiation dose on fruit firmness, however, was dependent on the storage temperature. Mature green fruit ripened at $25{ }^{\circ} \mathrm{C}$ lost less weight than did those stored at cold temperatures prior to ripening. We recommend that importers obtain fruit with only a slight break in ground color, and distribute them as rapidly as possible, while maintaining transit/storage temperatures at or above $15{ }^{\circ} \mathrm{C}$ with or without exposure to irradiation.
\end{abstract}

Papaya fruit grown under approved flyfree zone protocol [Mediterranean fruit fly Ceratitis capitata (Weidemann) (MFF)] are imported into the United States from Belize through the Port of Miami, Fla. The groves in Belize could lose fly-free certification, thus requiring the importer to subject these papaya to a quarantine treatment. Approved disinfestation treatments for fruit flies $\{\mathrm{MFF}$, Oriental fruit fly [Dacus dorsalis (Hendel)], and the melon fly [Bactrocera cucurbitae (Coquillett)]\} infesting papaya include: 1) multistage high-temperature forced air (HTFA); 2) single stage HTFA; 3 ) vapor heat (U.S. Dept. of Agriculture, 1994); or 4) lowdose irradiation (Federal Register, 1996a).

Received for publication 17 Aug. 1998. Accepted for publication 15 Mar, 1999. Mention of a trademark, warranty, proprietary product, or vendor does not constitute a guarantee by the U.S. Dept. of Agriculture (USDA) and does not imply its approval to the exclusion of other products or vendors that may also be suitable. We acknowledge the assistance and arrangements for fruit supplied by $\mathrm{M}$. Trunk, Brooks Tropicals, Inc., and V. Chew and C.C. Carroll, Statistician, USDA, Gainesville, Fla., and Biological Scientist, Univ. of Florida, Institute of Food and Agricultural Sciences, Research and Education Center, Ft. Pierce, Fla., respectively, for their professional expertise. The cost of publishing this paper was defrayed in part by the payment of page charges. Under postal regulations, this paper therefore must be hereby marked advertisement solely to indicate this fact.
Low-dose irradiation is approved, at doses of at least $250 \mathrm{kGy}$, for fresh-market papaya grown in Hawaii and shipped to the U.S. mainland (Federal Register, 1996b). Papaya harvested at the MG to QY stage tolerate absorbed doses of irradiation to $1.0 \mathrm{kGy}$; however, physiological disorders may develop above $1.0 \mathrm{kGy}$. Moy et al. (1973) also found that pulp of irradiated fruit remained firm longer than did that of nonirradiated fruit even though peel and pulp color changed normally. In South Africa, Brodrick et al. (1976) used a combination of heat $\left(50{ }^{\circ} \mathrm{C}\right.$ for $\left.10 \mathrm{~min}\right)$ and irradiation $(0.75 \mathrm{kGy})$ treatments to control decay and extend papaya shelf life. Paull (1996) found that the ripening response of papaya after irradiation $(0.25 \mathrm{kGy})$ treatment was dependent on the stage of fruit ripeness at treatment. Irradiated MG fruit did not soften, but ripened abnormally compared with nonirradiated fruit, and irradiated fruit with $30 \%$ color break softened at a slower rate than did nonirradiated fruit. He reported that irradiated fruit stored at $10{ }^{\circ} \mathrm{C}$ after irradiation developed peel scald; however, this condition was inhibited by delaying cold storage by $12 \mathrm{~h}$. In a separate study, the effect of irradiation dose on papaya firmness was linear, yet dose did not affect peel or pulp color when applied to fruit with $5 \%$ and $30 \%$ yellow peel prior to ripening (Zhao et al., 1996). They also reported that irradiation both depolymerized and demethoxylated the pectin in fruit with $10 \%$ to
$30 \%$ peel color, but did not affect pectin methylesterase activity; irradiated fruit remained firmer for $2 \mathrm{~d}$ longer than did nonirradiated control fruit. The lowest nonchilling temperature for solo-type papaya was between 12.5 and $15^{\circ} \mathrm{C}$ under shipping and storage conditions based on fruit susceptibility to Alternaria alternata (Fr.) Keissler (Sommer and Mitchell, 1978), and Paull et al. (1997) described the time/temperature relationship of maturity during storage. The purpose of our investigation was to determine the lowest storage temperature that irradiated papayas can tolerate, following exposure to the maximum irradiation dose required for fruit fly disinfestation, using pallet unit handling $(\approx 0.675 \mathrm{kGy})$ in commercial irradiation treatment facilities.

\section{Materials and Methods}

'Sunrise Solo 'papaya fruit were harvested from 1- to 2-year-old trees in Belize groves that were maintained under certified Mediterranean fly-free zone protocol. At harvest, fruit were mature and peel color ranged from MG to QY color break. Fruit were placed into plastic field crates $(\approx 8 \mathrm{~kg})$, and taken to a local packinghouse, where they were graded, sized, washed [chlorinated water $\left.\left(2 \mathrm{~mL} \cdot \mathrm{L}^{-1}\right)\right]$, and dipped in an aqueous solution of thiabendazole (2-4-thiazolyl benzimidazole) $\left(1 \mathrm{~mL} \cdot \mathrm{L}^{-1}\right)$. Within $12 \mathrm{~h}$ of harvest, fruit were individually cushioned with heavy gauge kraft-type paper and packed 10 per full-telescoping fiberboard papaya box $(33.0 \times 29.2 \times 15.2 \mathrm{~cm})$ with vent holes in all six sides. Palletized units of papaya fruit (144 boxes each) were placed into "forced air" cold rooms (relative humidity $90 \% \pm 5 \%$ ) set at $12.8^{\circ} \mathrm{C}$ for $4 \mathrm{~h}$ until mean fruit temperature reached $15^{\circ} \mathrm{C}$. Fruit remained in refrigerated storage at $12.8^{\circ} \mathrm{C}$ until loaded into refrigerated (set at $11^{\circ} \mathrm{C}$ ) marine containers. Fruit were transported from the packinghouse to the port of Belize City for weekly shipments to the Port of Miami. On arrival, fruit were cleared through customs and transported to the Brooks Tropicals, Inc., refrigerated warehouse located in Homestead, Fla.

Papaya were obtained for this study on three occasions (28 Aug., 11 and 25 Sept. 1997). Fruit were of two maturity stages based on degree of peel color break: 1) mature with green peel (MG); and 2) fruit at or near onequarter yellow (QY) color. The harvest dates of MG and QY fruit for each test varied by 1 to $3 \mathrm{~d}$, and for each test MG or QY fruit were harvested from different groves. Each maturity lot (MG or QY) consisted of 16 boxes for a total of 32 boxes for each of the three tests. All fruit were transported by an air-conditioned auto (4-h trip) to the U.S. Horticultural Research Laboratory in Orlando, Fla. Fruit were randomized, identified, and initial fruit weight was recorded. They were held overnight at $20^{\circ} \mathrm{C}$ and irradiated the following morning. The main factors of treatment were: 1) two stages of ripeness ( $1=\mathrm{MG} ; 2=\mathrm{QY}), 2)$ two irradiation doses $(0 ; 0.675 \mathrm{kGy})$, and 3$)$ four storage temperatures $\left(25\right.$, or $10,12,15^{\circ} \mathrm{C}$ for $7 \mathrm{~d}$, then ripened at $25^{\circ} \mathrm{C}$ ). Each of the 16 
treatment combinations consisted of two sample boxes of 10 fruit each for a total of 320 fruit per test. One-half of each fruit lot was irradiated at a mean dose of $0.675 \mathrm{kGy}$ (Gammachrome YR Dosimeters, range 0.1$3.0 \mathrm{kGy}$, Harwell Laboratory, Oxfordshire, U.K.), applied at $0.12 \mathrm{kGy} \cdot \mathrm{min}^{-1}$ by a ${ }^{60} \mathrm{Co}$ source [Food Technology Services (FTS), Inc., Mulberry, Fla.]. Immediately after irradiation, fruit were moved to the laboratory (1.5-h trip) and placed at $20^{\circ} \mathrm{C}$ for $4.5 \mathrm{~h}$, during which the initial evaluation of peel color and firmness was completed.

Six hours after the irradiation treatment, fruit were placed at $25^{\circ} \mathrm{C}$ to ripen or at 10,12 , or $15^{\circ} \mathrm{C}$ storage. Fruit immediately held at 25 ${ }^{\circ} \mathrm{C}$ were observed daily until ripe. Fruit held in cold storage were reweighed, inspected after 7 $\mathrm{d}$, then placed at $25^{\circ} \mathrm{C}$ until each fruit reached the eating ripe stage. When ripe, all fruit were scored for incidence and severity of scald. Scald developed as randomly shaped, discolored areas on the fruit peel. The severity of scald was rated as: 1) no injury, 2) $<10 \%, 3$ ) $10 \%$ to $<25 \%, 4) 25 \%$ to $50 \%$, and 5) $>50 \%$ of fruit surface area. The incidence of fruit with hard, lumpy areas in the pulp of mesocarp tissue after ripening was also determined. The incidence of decay was calculated on a per fruit basis, but the causal organisms were not positively identified. An Instron Food Texture machine (model 4411; Instron Corp., Canton, Mass.) calibrated to record the force $(\mathrm{N})$ required to force an 8-mm-diameter cylinder, 5 $\mathrm{mm}$ deep into the flesh at $25 \mathrm{~cm} \cdot \mathrm{min}^{-1}$ was used to measure pulp firmness. Objective pulp firmness was measured at the midpoint between the peel and cavity on two sides of a $2.5-\mathrm{cm}$ wide wedge of pulp removed from an equatorial section of each fruit. In addition, objective pulp color was measured at one site on each side of the pulp wedge used for firmness measurement with a Chroma Meter (model CR 200; Minolta Camera Co., Osaka, Japan). Color was measured in the $\mathrm{L}^{*}, \mathrm{a}^{*}, \mathrm{~b}^{*}[\mathrm{Com}-$ mission of International Color (CIE), 1976] color mode, and hue and chroma values were calculated. Subjective peel color categories used were: 1) green; 2) <1/4 yellow; 3) $1 / 4$ to $1 / 2 ; 4)>1 / 2$ to $3 / 4 ; 5$ ) $>3 / 4$ yellow color; and 6) orange blush/yellow. Weight loss was calculated by recording the weight of each fruit initially at fruit preparation and again after ripening.

Subjective fruit firmness combined with peel color was used to determine "edible" or soft ripe. Subjective firmness was based on the whole fruit resistance to moderately applied finger pressure (MAFP) and rated: $1=$ firm (resistance to MAFP); 2 = fairly firm (moderate resistance to MAFP); 3 = fairly soft (slight resistance to MAFP); and $4=$ soft (very slight resistance to MAFP). Completion of ripening was determined for each fruit subjectively, when a peel color of 5 and subjective firmness of 3 or 4 was reached. Days to ripen was determined on each fruit of two harvests only. Days to ripen was defined as the time between removal from cold storage and edible ripe stage. Ripening time for those fruit stored continuously at $25{ }^{\circ} \mathrm{C}$ was adjusted by sub- tracting $7 \mathrm{~d}$ to permit comparison with fruit stored for $7 \mathrm{~d}$ at lower temperature.

A 100-g sample of each soft ripe fruit was chopped, placed into a freezer bag and held at $-20{ }^{\circ} \mathrm{C}$ for total soluble solids (TSS) and $\mathrm{pH}$ determination using standard methods. Sensory evaluations were made on transverse wedges of each fruit and scored as acceptable or unacceptable for flavor or mastication texture by persons conducting the evaluations.

The mean values of each attribute were tested for differences among treatments, and significances determined for main factors and among all interactions by analysis of variance (ANOVA) procedures (SAS Institute, 1998).

\section{Results}

Incidence and severity of scald. The incidence of scald was less on fruit immediately ripened at $25^{\circ} \mathrm{C}$ than on fruit held for $7 \mathrm{~d}$ at various temperatures and then ripened (Table 1), and on irradiated MG fruit than on comparable QY fruit. Nonirradiated fruit was not affected by incidence of scald regardless of fruit maturity.

Pulp firmness. Firmness of QY fruit was higher and tended to decrease more as storage temperature increased compared with similarly treated MG fruit (Table 1). The significant dose $\times$ storage temperature interaction indicated that the firmness of irradiated fruit was higher than that of nonirradiated fruit except for those stored at $10{ }^{\circ} \mathrm{C}$.

Pulp lumpiness (uneven softening). At the edible stage, some papayas had hard areas of pulp, either as small spherical areas of tissue or as relatively thin layers of hard tissue at the middle mesocarp. There was a significant $(P \leq$ $0.05)$ interaction between stage of maturity, irradiation dose, and storage temperature (Fig. $1 \mathrm{~A}$ and $\mathrm{B}$ ). Lumpiness was greater for QY than for MG fruit, except for irradiated MG fruit at $10{ }^{\circ} \mathrm{C}$, which had the highest overall incidence of lumpiness. The incidence of lumpiness in stored fruit tended to decrease as storage temperature increased, again with the exception of irradiated MG fruit at $10{ }^{\circ} \mathrm{C}$. Irradiated fruit tended to have a higher incidence of lumpiness than did nonirradiated fruit. Fruit stored and ripened at $25^{\circ} \mathrm{C}$ had less lumpiness, whether irradiated or not, than did fruit held in storage and then ripened.

Decay. Interaction among the main factors of stage of maturity, irradiation dose, and storage temperature for decay was significant $(P \leq 0.05)$ (Fig. $1 \mathrm{~B}$ and $\mathrm{C}$ ). The lowest incidence of decay occurred in MG fruit ripened at $25{ }^{\circ} \mathrm{C}$ regardless of irradiation treatment. Nonirradiated, stored MG fruit had a similar incidence of decay, whereas decay in irradiated MG fruit increased with storage temperature. Fruit of QY stored for $7 \mathrm{~d}$ tended to have higher incidences of decay than did similarly treated MG fruit regardless of irradiation treatment. Most decay was caused by Anthracnose sp. or stem-end-rot organisms.

Pulp color. The effect of initial fruit maturity on the $L^{*}$ index value $(0=$ black, $100=$ white) was dependent on storage temperature.

Table 1. Effects of irradiation $(0.675 \mathrm{kGy})$ and subsequent storage for $7 \mathrm{~d}$ at 10,12 , or $15^{\circ} \mathrm{C}$ on quality ratings for mature green (MG) or quarter yellow (QY) papayas ripened at $25^{\circ} \mathrm{C}$.

\begin{tabular}{|c|c|c|c|c|c|c|c|c|c|c|c|}
\hline Maturity & Irrad. & $\begin{array}{c}\text { Storage } \\
\left({ }^{\circ} \mathrm{C}\right)\end{array}$ & $\begin{array}{c}\text { Scald } \\
(\%)\end{array}$ & $\begin{array}{l}\text { Scald } \\
\text { index }\end{array}$ & $\begin{array}{c}\text { Firmness } \\
(\mathrm{N})\end{array}$ & $\begin{array}{c}\mathrm{L}^{*} \\
\text { value }\end{array}$ & $\begin{array}{l}\mathrm{h}^{*} \\
\text { hue }\end{array}$ & $\begin{array}{c}\mathrm{C}^{*} \\
\text { chroma }\end{array}$ & $\begin{array}{l}\mathrm{TSS}^{\mathrm{z}} \\
(\%)\end{array}$ & $\mathrm{pH}$ & $\begin{array}{c}\text { Wt loss } \\
(\%)\end{array}$ \\
\hline \multirow{10}{*}{ MG } & - & 25 & 1.7 & 1.0 & 4.5 & 53.2 & 49.6 & 47.1 & 12.8 & 5.04 & 3.0 \\
\hline & & 10 & 40.0 & 1.7 & 7.3 & 53.0 & 50.0 & 45.8 & 12.5 & 5.12 & 5.0 \\
\hline & & 12 & 35.0 & 1.9 & 6.0 & 52.4 & 49.0 & 47.0 & 12.5 & 5.09 & 5.2 \\
\hline & & 15 & 31.7 & 1.7 & $\underline{6.3}$ & 53.7 & $\underline{50.2}$ & $\underline{46.5}$ & $\underline{12.5}$ & $\underline{5.02}$ & $\underline{5.8}$ \\
\hline & & Mean & $\overline{27.1}$ & $\overline{1.6}$ & $\overline{6.0}$ & $\overline{53.1}$ & $\overline{49.7}$ & $\overline{46.6}$ & $\overline{12.6}$ & $\overline{5.07}$ & $\overline{4.8}$ \\
\hline & + & 25 & 3.3 & 1.0 & 5.4 & 53.5 & 49.9 & 47.6 & 12.7 & 5.12 & 4.1 \\
\hline & & 10 & 65.0 & 2.5 & 5.8 & 53.6 & 50.8 & 44.7 & 12.4 & 5.17 & 4.8 \\
\hline & & 12 & 50.0 & 2.0 & 8.1 & 52.9 & 49.7 & 47.5 & 12.7 & 5.08 & 5.5 \\
\hline & & 15 & 56.7 & 2.2 & 7.5 & 53.6 & $\underline{50.5}$ & 47.9 & 12.5 & 5.09 & 6.5 \\
\hline & & Mean & 43.8 & 1.9 & 6.7 & $\frac{53.4}{53.4}$ & 50.2 & 46.9 & 12.6 & 5.12 & $\frac{5}{5.2}$ \\
\hline \multirow[t]{12}{*}{ QY } & - & 25 & 0.0 & 1.0 & 6.2 & 54.0 & 50.5 & 48.0 & 12.2 & 5.06 & 4.8 \\
\hline & & 10 & 35.0 & 1.8 & 11.6 & 54.2 & 51.9 & 47.1 & 11.8 & 5.06 & 6.6 \\
\hline & & 12 & 41.7 & 2.0 & 8.5 & 53.5 & 51.2 & 48.0 & 12.0 & 5.04 & 6.3 \\
\hline & & 15 & 28.3 & 1.8 & 5.7 & $\underline{53.3}$ & $\underline{50.8}$ & 47.7 & 12.0 & 5.07 & 7.1 \\
\hline & & Mean & 26.3 & $\frac{1.0}{1.7}$ & 8.0 & 53.8 & 51.1 & 47.7 & 12.0 & 5.06 & 6.2 \\
\hline & + & 25 & 18.3 & 1.3 & 5.9 & 53.9 & 50.9 & 48.8 & 12.1 & 5.08 & 4.4 \\
\hline & & 10 & 70.0 & 3.1 & 10.0 & 55.3 & 52.0 & 47.1 & 11.8 & 5.06 & 6.6 \\
\hline & & 12 & 73.3 & 3.1 & 11.3 & 54.7 & 52.0 & 48.8 & 11.8 & 5.02 & 6.8 \\
\hline & & 15 & $\underline{58.3}$ & 2.6 & 7.4 & $\underline{54.0}$ & $\underline{51.5}$ & 49.0 & 11.7 & $\underline{5.00}$ & 7.2 \\
\hline & & Mean & $\overline{55.0}$ & $\overline{2.5}$ & 8.7 & $\overline{54.5}$ & $\overline{51.6}$ & $\overline{48.4}$ & $\overline{11.9}$ & $\overline{5.04}$ & $\overline{6.3}$ \\
\hline & & Mean & 38.0 & 1.9 & 7.4 & 53.7 & 50.7 & 47.4 & 12.3 & 5.07 & 5.6 \\
\hline & & LSD & 22.0 & 0.6 & 3.4 & 1.4 & 1.8 & 1.5 & 0.4 & 0.05 & 1.8 \\
\hline \multicolumn{12}{|c|}{ Main factors and interactions $\mathrm{s}^{\mathrm{y}}$} \\
\hline \multicolumn{3}{|c|}{ Maturity (M) } & NS & * & $*$ & $*$ & $*$ & $*$ & $*$ & * & $*$ \\
\hline \multicolumn{2}{|c|}{ Dose (D) } & & $*$ & $*$ & NS & $*$ & $*$ & $*$ & NS & NS & NS \\
\hline \multicolumn{2}{|c|}{ Temp (T) } & & * & $*$ & $*$ & NS & * & * & $*$ & NS & $*$ \\
\hline \multicolumn{2}{|c|}{$\mathrm{M} \times \mathrm{D}$} & & $*$ & $*$ & NS & NS & NS & NS & NS & NS & NS \\
\hline \multicolumn{2}{|c|}{$\mathrm{M} \times \mathrm{T}$} & & NS & NS & $*$ & $*$ & NS & NS & NS & NS & NS \\
\hline $\mathrm{D} \times \mathrm{T}$ & & & NS & $*$ & $*$ & NS & NS & * & NS & NS & NS \\
\hline
\end{tabular}

${ }^{2}$ Total soluble solids.

${ }^{\mathrm{y}}$ Interactions not shown were nonsignificant for all attributes.

ss, *Nonsignificant or significant by ANOVA $(P \leq 0.05)$. 
Under all storage conditions, QY fruit tended to be lighter in color after ripening than were MG fruit. Mean hue values for MG and QY fruit after ripening were 50 and 51.3 , respectively; values for nonirradiated and irradiated fruit were 50.4 and 50.9, respectively (Table 1 ). The magnitude of differences for the main factors was small. Irradiated fruit tended to have higher $\mathrm{C}^{*}$ values, indicating brighter yellow pulp than nonirradiated fruit, except for those fruit held at $10{ }^{\circ} \mathrm{C}$ and ripened at 25 ${ }^{\circ} \mathrm{C}$.

Total soluble solids and $p H$. Fruit ripened at $25^{\circ} \mathrm{C}$, or those held at 10,12 , or $15^{\circ} \mathrm{C}$ and then ripened, had TSS values of $12.45 \%$, $12.12 \%, 12.25 \%$, and $12.18 \%$, respectively (Table 1). There was no effect of irradiation on TSS, and there was little or no difference in $\mathrm{pH}$ among treatments.

Weight loss. MG and QY fruit lost an average of $5.0 \%$ and $6.2 \%$ in fresh weight during storage, respectively (Table 1 ). Weight loss was affected by storage temperature; fruit ripened at $25^{\circ} \mathrm{C}$, or stored at 10,12 , or $15^{\circ} \mathrm{C}$ and then ripened, decreased in weight by $4.1 \%$, $5.8 \%, 6.0 \%$, and $6.7 \%$, respectively. Irradiation treatment had no effect on weight loss.

Days to ripen and pulp flavor. There was a significant interaction among fruit maturity, irradiation dose, and storage temperature $(P \leq$ 0.05 ), and between maturity and irradiation dose (Fig. 2 A and B). Ripening was slightly slower in MG than in QY fruit. Irradiation delayed ripening of $\mathrm{MG}$ fruit more than of QY fruit, except for fruit stored at $15^{\circ} \mathrm{C}$ and then ripened.

Acceptability of pulp flavor and mastication texture of pulp was evaluated only by the persons making condition and quality evaluations. Pulp flavor was rated acceptable for most fruit at the soft ripe stage. Some fruit held at $10^{\circ} \mathrm{C}$ and ripened at $25^{\circ} \mathrm{C}$ tended to have a less than full flavor, and the consistency of the pulp tended to be slightly mushy (very softened). Fruit flavor was not affected by irradiation treatment. The flavor of fruit with a high amount of surface decay also was less preferred than that of fruit with less area of decay.

\section{Discussion}

The papaya fruit used in this study ripened relatively rapidly. This was probably due to the export handling situation dictated by growing fruit in Belize and surface shipping of the fruit to the Port of Miami for distribution throughout the United States and Canada. The papaya were subjected to $\approx 5$ to $7 \mathrm{~d}$ storage/ transport at temperatures of 11 to $13{ }^{\circ} \mathrm{C}$ prior to the irradiation treatment. Sommer and Mitchell (1978) reported that $12.5^{\circ} \mathrm{C}$ may be the lowest non-chill storage temperature for solo-type papaya grown in Hawaii. At this temperature fruit resistance to rot from Alternaria alternata (Fr.) was reduced, even though no visible symptom of chilling injury was observed.

Scald or irregular areas of peel discoloration were observed on both irradiated and nonirradiated fruit at all storage temperatures. Paull (1996) also observed peel scald on irra-

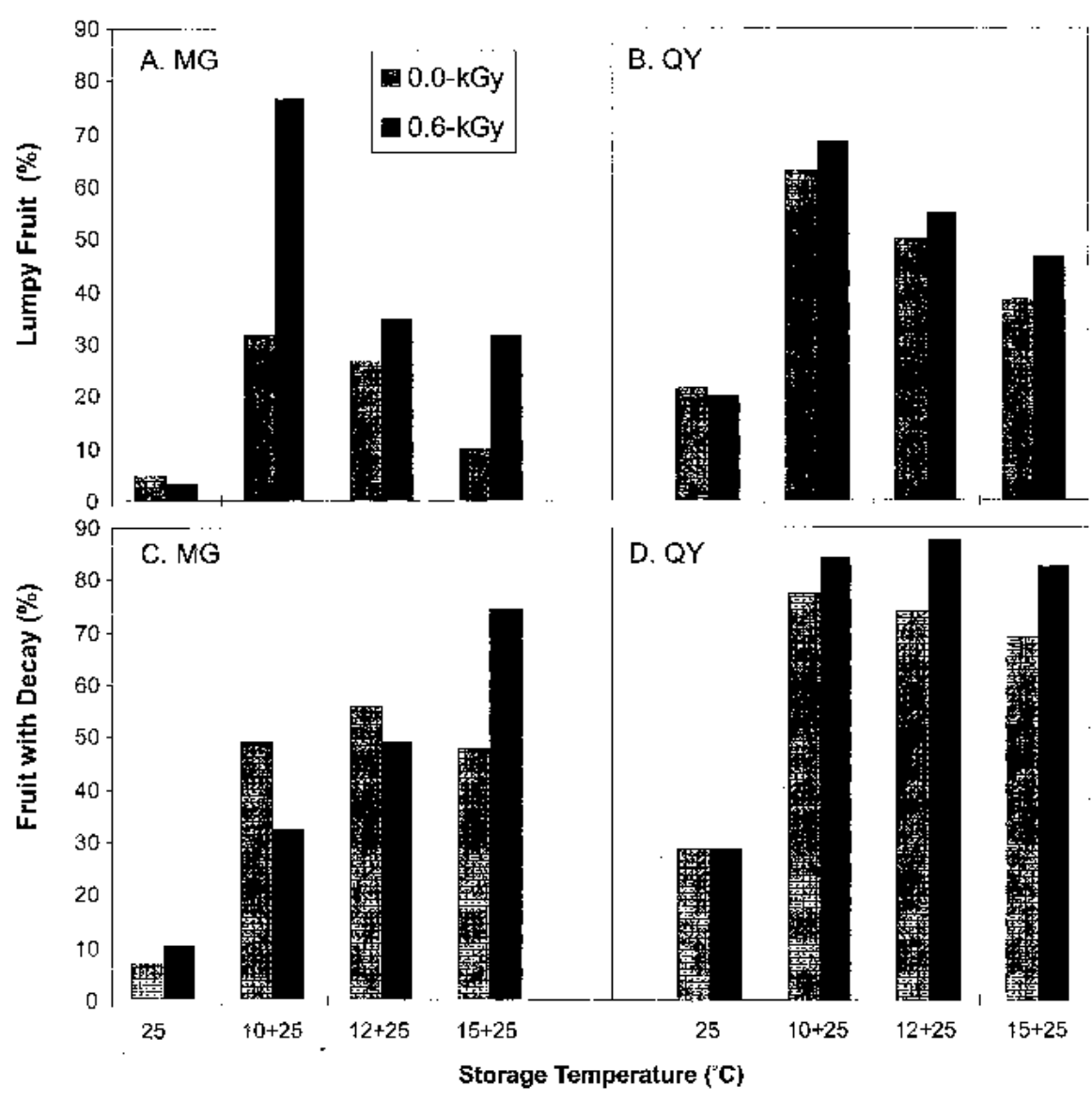

Fig. 1. Effects of irradiation and subsequent storage for $7 \mathrm{~d}$ at 10,12 , or $15^{\circ} \mathrm{C}$ on incidence of pulp lumpiness $(\mathbf{A}, \mathbf{B})$ and decay $(\mathbf{C}, \mathbf{D})$ in mature green $(\mathrm{MG})$ and quarter-yellow $(\mathrm{QY})$ papaya fruit after ripening at $25^{\circ} \mathrm{C}$. Means for three harvests. Vertical bars indicate LSD at $P \leq 0.05$.

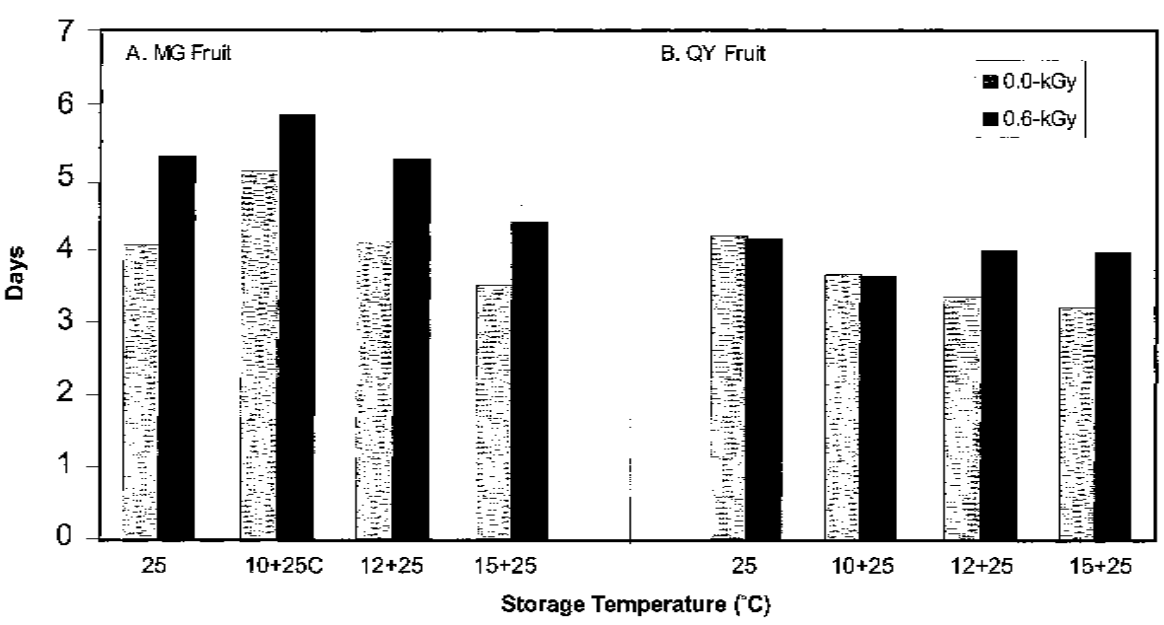

Fig. 2. Effects of irradiation and subsequent storage for $7 \mathrm{~d}$ at 10,12 , or $15^{\circ} \mathrm{C}$ on time for mature green (MG) and quarter-yellow (QY) papaya fruit to reach edible ripe stage when held at $25^{\circ} \mathrm{C}$. Means for two harvests. Vertical bars indicate LSD at $P \leq 0.05$. 
diated fruit placed immediately at $10{ }^{\circ} \mathrm{C}$, but delaying cold storage for $12 \mathrm{~h}$ after irradiation treatment inhibited the development of scald. We delayed placement of fruit in storage at 10 , 12 , and $15^{\circ} \mathrm{C}$ for $6 \mathrm{~h}$ following irradiation treatment. Only nonirradiated fruit ripened immediately at $25{ }^{\circ} \mathrm{C}$ developed little to no scald. For unknown reasons the incidence of scald tended to be greater for QY than for MG fruit, but the magnitude of difference by fruit maturity was dose-dependent. In general, QY fruit had higher incidences of lumpiness regardless of irradiation treatment or storage temperature, except for irradiated MG fruit stored at $10{ }^{\circ} \mathrm{C}$ prior to ripening. Lumpiness has been reported to be a symptom of chilling injury in papaya (Chen and Paull, 1986). Clearly, fruit lumpiness tended to decline as storage temperature increased, but we observed lumpiness in all treatments. Paull (1996) reported no abnormal ripening following irradiation, but observed that irradiated fruit with $30 \%$ color break softened at a slower rate than did control fruit of similar maturity. Our sample fruit were not exposed to storage temperatures that would cause chilling injury. The reason for the high incidence of lumpiness is unknown.

The incidence of surface decay was generally high. Decay was manifested more in QY than in MG fruit probably because of the higher incidence of peel injuries during handling; decay organisms are known to enter fruit at sites of injury. In addition, transport/ storage temperatures of $11{ }^{\circ} \mathrm{C}$ may have reduced fruit resistance to decay, as suggested by Sommer and Mitchell (1978), even though chilling injury symptoms were not observed.

Based on firmness of pulp after ripening, we generally observed that QY fruit had firmer pulp than did MG fruit regardless of irradiation treatment. Paull (1996) found that irradiated "color break fruit" softened at a slower rate than did nonirradiated fruit. Zhao et al. (1996) reported that the effect of irradiation dose manifested after fruit ripening was greater on fruit with $25 \%$ to $30 \%$ yellow color than on those with $15 \%$ to $20 \%$. Our results generally confirm these findings. However, the difference in degree of color break between $\mathrm{MG}$ and QY fruit in our study was less than the color break categories defined by Zhao et al. (1996).
Contrasting differences between Zhao's findings and our results are further complicated by different handling procedures prior to irradiation treatment, as well as storage temperatures used.

Total soluble solids values were higher in MG than in QY fruit; this is consistent with Chan et al.'s (1979) report that total sugars drop $\approx 135 \mathrm{~d}$ after anthesis. Time to ripen was generally greater for MG than for QY fruit. Nonirradiated MG fruit held at $10{ }^{\circ} \mathrm{C}$ had the greatest delay in ripening of all treatments. Note the tendency for less delay in ripening of MG fruit as storage temperature increased from 10 to $15^{\circ} \mathrm{C}$. Time to ripen was less affected by storage temperature in QY than in MG fruit. Differences in pulp color among treatment combinations, while significant, are of little commercial importance.

Based on our findings, continued investigations are warranted to evaluate partial ripening of MG fruit at $25^{\circ} \mathrm{C}$ immediately after arrival at the Port of Miami until $\approx 25 \%$ yellow color, and then irradiating prior to shipping to market. This procedure may result in the highest quality and least injury upon finally reaching the full edible ripe stage. Temporary storage is necessary when shipping papaya by surface transport. We suggest reducing cold storage time as much as possible. This may be accomplished by shipping only fruit that are harvested within the previous 2 to $3 \mathrm{~d}$, shipping on more rapid vessels, and reducing time fruit are held at ports. The most negative impacts on quality of papaya fruit were decay, pulp lumpiness (uneven ripening), and excessive pulp firmness at the edible ripe stage. Chan (1988) described these same disorders for papaya following cold temperature stress, and showed the effect of stage of maturity on the development of such disorders. Although the fruit in our study were not exposed to temperatures below $11^{\circ} \mathrm{C}$ prior to arrival, they developed symptoms similar to those caused by low temperatures as described in the chilling injury time/temperature boundary study by Chen and Paull (1986). This suggests that these symptoms are not confined to chilling injury.

Shipping papaya under refrigerated storage conditions, and delaying ripening for $7 \mathrm{~d}$, with or without exposure to irradiation on arrival at the country of importation, is a risky procedure for the maintenance of product quality. Partial ripening of papaya to $25 \%$ yellow color at $25^{\circ} \mathrm{C}$ after arrival and before treatment would probably allow $\approx 4$ to $5 \mathrm{~d}$ for distribution of fruit before they reached the edible ripe stage.

\section{Literature Cited}

Brodrick, H.T., A.C. Thomas, and M. Beyers. 1976. Studies on the use of gamma irradiation and hot water treatments for shelf life extension of papayas. Plant Dis. Rptr. 60:749-753.

Chan, H.T. Jr. 1988. Alleviation of chilling injury in papaya. HortScience 23:868-870.

Chan, H.T. Jr., K.L. Hibbard, T. Goo, and E.K. Akamine. 1979. Sugar composition of papayas during fruit development. HortScience 14:140 141.

Chen, N.-M. and R.E. Paull. 1986. Development and prevention of chilling injury in papaya fruit. J. Amer. Soc. Hort. Sci. 111:639-643.

Federal Register. 1996a. The application of irradiation to phytosanitary problems. Fed. Reg. 61(95):24433-24439.

Federal Register. 1996b. Papaya, carambola and litchi from Hawaii. Fed. Reg. 61(142):3803-3814.

Moy, J.H., E.K. Akamine, N. Wenkan, A.M. Dollar, M. Hanaoka, Y.Y. Kao, W.L. Liu, and L.M. Revetti. 1973. Tolerance, quality and shelf-life of gamma-irradiated papaya grown in Hawaii, Taiwan, and Venezuela, p. 375-387. In: Radiation preservation of food. Intl. Atomic Energy Agency, Vienna.

Paull, R.E. 1996. Ripening behavior of papaya (Carica papaya L.) exposed to gamma irradiation. Postharvest Biol. Technol. 7:359-370.

Paull, R.E., W. Nishijima, M. Reyes, and C. Davaletoo. 1997. Postharvest handling and losses during marketing of papaya (Carica papaya $\mathrm{L}$.). Postharvest Biol. Technol. 11:165-179.

SAS Institute. 1998. SAS/STAT user's guide, release 6.01. SAS Inst., Cary, N.C.

Sommer, N.F. and F.G. Mitchell. 1978. Relation of chilling temperatures to postharvest alternaria rot of papaya fruit. Proc. Trop. Reg. Amer. Soc. Hort. Sci. 22:40-47.

U.S. Dept. of Agriculture Treatment Manual. 1994 Animal and Plant Health Insp. Serv. Plant Protection and Quarantine. Sec. T103, T106.p 5.51, 5.57.

Zhao, M., J. Moy, and R.E. Paull. 1996. Effect of gamma-irradiation on ripening papaya pectin. Postharvest Biol. Technol. 8:209-222. 